\title{
Dealing with Snakes in Florida's Residential Areas - Preventing Encounters ${ }^{1}$
}

\section{Steve A. Johnson and Monica E. McGarrity ${ }^{2}$}

Open spaces that provide homes for snakes and other wildlife are disappearing as more and more of natural Florida is developed to support the states booming human population. As natural areas disappear and become more divided by development, snakes are forced to eke out a living in the remaining fragments of habitat, which with increasing frequency are yards and gardens in residential areas. The end result is that people and snakes are often forced to live in close proximity to one another. However, the likelihood of encountering a snake in a residential area is not great, because many of Florida's 44 species of native snakes simply do not inhabit areas dominated by people. Furthermore, the vast majority of snakes you may possibly find around your home pose no threat to people, and therefore there is no reason that people and most species of snakes cannot coexist peacefully.

Most snakes that you may encounter in residential areas are non-venomous and are simply trying to make a living in an environment that is all too often hostile to snakes. Threats to snakes in residential areas include cats and dogs, lawnmowers, people who misunderstand and fear snakes, as well as automobiles. If you encounter a snake in your yard it is best that you enjoy it from a distance and "leave it be" to eat rodents, slugs, and insect pests in your yard. Despite myths, Florida's snakes are not aggressive, and in fact many provide a valuable service by eating rodents that destroy property and potentially spread disease. Even though most snakes in residential areas are not a threat to people or pets, there are steps you can take to avoid encountering snakes.

In areas where human/snake encounters are likely, we recommend a three-part proactive approach for dealing with snakes, using the information provided in this series. By learning to identify Florida's most commonly encountered snakes, taking steps to prevent negative encounters, and planning for emergencies, you will be well equipped to coexist peacefully with snakes. You will also be prepared to identify potentially dangerous snakes and react appropriately if the need arises. This document provides information on the second step of this proactive approach - preventing negative encounters with snakes.

1. This document is WEC 221, the third in a 4-part series entitled "Dealing with Snakes in Florida's Residential Areas", of the Department of Wildlife Ecology and Conservation, University of Florida / IFAS. First published July 2007. Accompanying documents by Dr. Johnson related to dealing with snakes in a variety of settings are available through the University of Florida/EDIS at http://edis.ifas.ufl.edu/TOPIC_A23708620. A free PowerPoint presentation (with speaking notes) on the topic of venomous snake safety is available upon request from Steve A. Johnson by email - tadpole@ufl.edu.

2. Steve A. Johnson - Department of Wildlife Ecology and Conservation and Gulf Coast Research and Education Center, University of Florida IFAS/Plant City Campus, 1200 North Park Road, Plant City, FL 33563

Monica E. McGarrity - Gulf Coast Research and Education Center, University of Florida IFAS/Plant City Campus, Plant City, FL

The Institute of Food and Agricultural Sciences (IFAS) is an Equal Opportunity Institution authorized to provide research, educational information and other services only to individuals and institutions that function with non-discrimination with respect to race, creed, color, religion, age, disability, sex, sexual orientation, marital status, national origin, political opinions or affiliations. U.S. Department of Agriculture, Cooperative Extension Service, University of Florida, IFAS, Florida A. \& M. University Cooperative Extension Program, and Boards of County Commissioners Cooperating. Larry Arrington, Dean 


\section{PREVENTING NEGATIVE ENCOUNTERS WITH SNAKES}

For many people who are unfamiliar with snakes (or even fear them) the task of avoiding encounters with snakes may seem challenging. However, this is one case in which the motto "work smart, not hard" certainly holds true. Attempting to kill all the snakes in your yard is not the solution-rather you should learn how to make your yard and home less attractive to snakes, if your goal is to prevent encountering them. You should also learn how to tell the difference between harmless, non-venomous species and potentially dangerous, venomous snakes. Killing or attempting to kill snakes around your home greatly increases your chances of being bitten, and will not prevent other snakes from entering your yard. This may actually prove counterproductive, especially if you kill non-venomous snakes, some of which eat venomous snakes (not to mention helping to control rodent populations that could attract more snakes!). Attempting to completely exclude snakes from your yard with fencing is possible, but would be rather time consuming and expensive, and advertised "snake repellents" simply do not work. So how can you "work smart" to prevent unwanted encounters?

If you have already read the previous document in this series (Dealing with Snakes in Florida's Residential Areas - Identifying Commonly Encountered Snakes: http://edis.ifas.ufl.edu/UW258) you should be able to identify most of the snakes you may encounter in your yard. This is an especially important step, as it allows you to determine which snakes (if any) might pose a threat, identify possible food sources for snakes, and learn other potential solutions. For example, someone with harmless Eastern Garter Snakes in their yard might find that their backyard pond is full of frogs - one of its favorite prey items. An individual who encounters equally harmless ratsnakes in or around their home might be well advised to cover potential access points for snakes, and to take steps to remove rodent prey. Thus, by learning to identify, understand and respect our ecologically important native snakes, you and your family may simply be able to coexist peacefully with them. However, if you encounter venomous snakes, snakes inside your home, or simply feel the need to prevent all encounters with snakes, the following steps will help to "snake proof" your home.

\section{"Snake Proof" Your Yard}

First, you should address your yard - do you have tall grass, overgrown shrubs or piles of brush, debris, or wood? If so, these may provide hiding spots for snakes, and tall grass can make it difficult to watch your step. Keep your grass mowed, and keep shrubs and tree branches trimmed away from the house. Do not mow to the edge of lakes or ponds, as this will destroy important habitat for frogs, turtles, and birds - rather, warn children to stay away from the water unless accompanied by an adult and keep pets away from these areas. Installing chain-link or privacy fence is an effective solution to keep pets and children away from wetland and lake edges. You should not completely remove brush piles and vegetation from your yard because these can provide habitat for wildlife, but should keep brush piles well away from buildings and areas where children play. Piles of firewood should also be moved away from these areas, and firewood should be stored neatly on a rack, rather than on the ground (Figure 1).

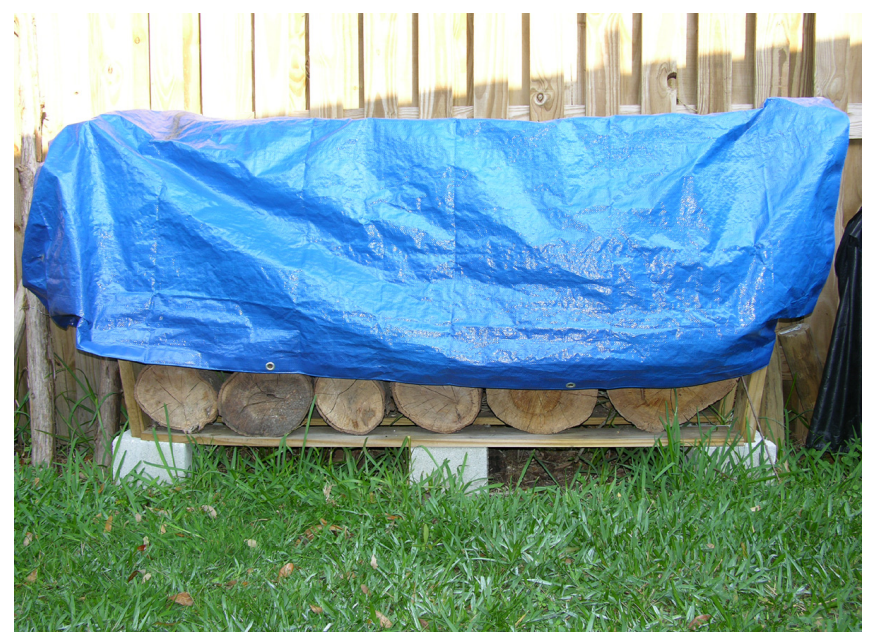

Figure 1. Firewood should be stacked neatly on a rack. Wood piles on the ground provide many hiding spots for snakes. Credits: Steve A. Johnson, University of Florida, 2007

Some landscape elements, such as rock walls, may also provide shelter for snakes (and rodents), and should be kept well away from the house unless cracks are sealed with mortar. Also, be alert when playing or working in your yard to avoid being 
surprised if you suddenly see a snake. Remember, snakes are most active in spring and summer.

\section{"Snake Proofing" Your Home and Other Structures}

Next, you should examine your house, garage, shed (or other outbuildings), and porch. Are there gaps under doors, holes in walls, or openings on your roof that might allow snakes to easily enter your home? Are there any holes or gaps in the screens on your windows, doors, or porch, or open drain pipes from enclosed pools? Snakes may enter garages, basements, or attics in search of prey if rodents are present or may simply slip in through a drain pipe or crack under a door in search of a cool hiding spot (Figure 2).

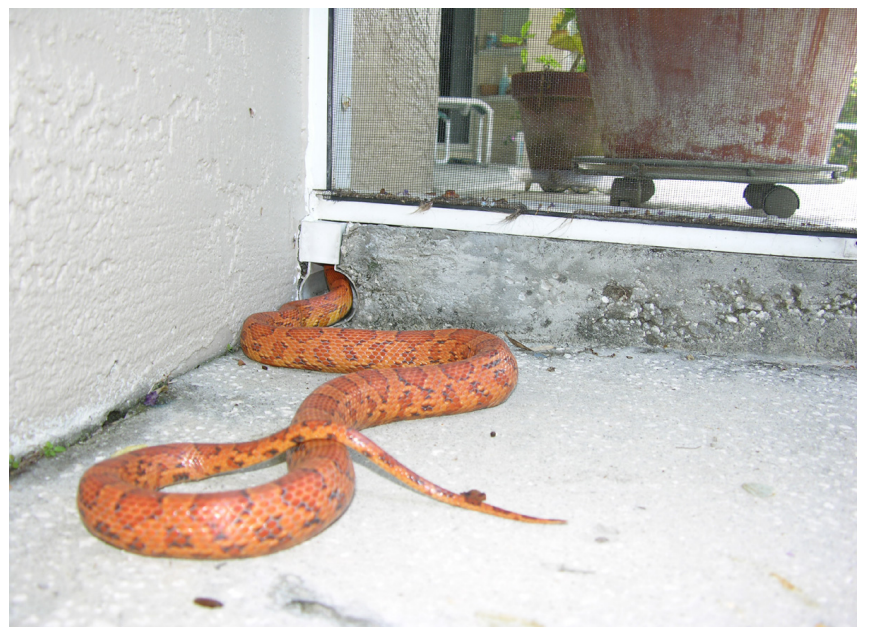

Figure 2. Uncovered holes, such as this patio pool drain are inviting hiding spots for snakes in search of a cool place to rest, and can allow a snake access to your home. Credits: Steve Johnson, University of Florida

As you inspect your home, you should keep in mind that some snakes (especially small ones) may enter through an opening no larger than a pencil.

Door sweeps and garage door threshold weather strips are easy, economical ways to seal gaps under doors, but must be checked periodically to ensure that they are in good repair (Figure 3). Caulking or inexpensive expansion foam sealant, available at hardware stores, can be used to seal cracks in a foundation, gaps between a patio or porch and the house, holes where wiring or plumbing enters your home, or gaps around attic vents (Figure 4). Larger gaps can be covered with hardware cloth, crawl space access holes can be fitted with secure doors, and plumbing vent stacks or other potential roof access points can be protected with inexpensive hardware cloth (Figure 5).

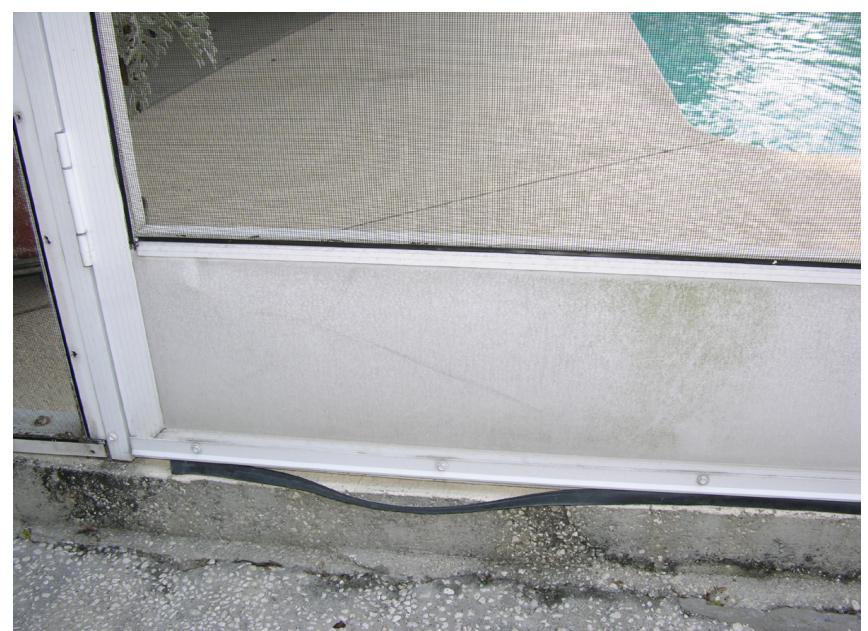

Figure 3. Door sweeps can prevent snakes from inadvertently slipping into the home under a door, but must be checked periodically. This rubber door strip is in disrepair, leaving large gaps beneath the door. Credits: Steve A. Johnson, University of Florida, 2007

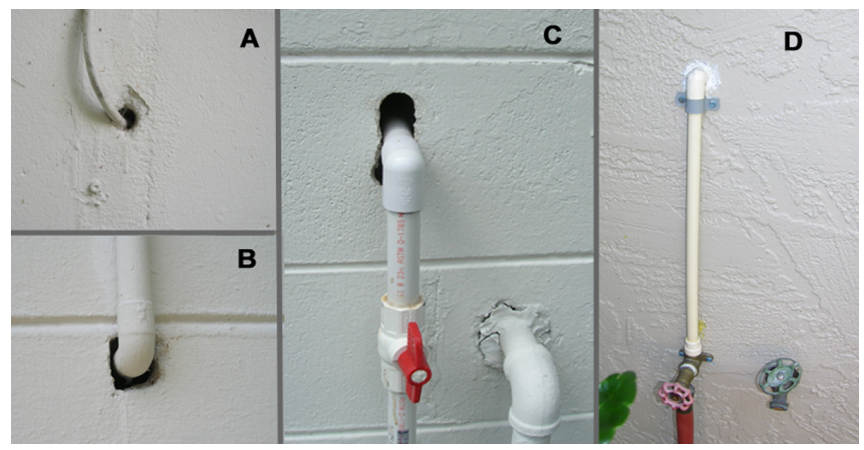

Figure 4. Small gaps where wiring $(A)$ or plumbing $(B)$ enter the house or garage can allow snakes to enter, and should be repaired with caulking. Larger gaps (C) can be filled with expansion foam sealant (D). Credits: Monica McGarrity and Steve Johnson, University of Florida, 2007

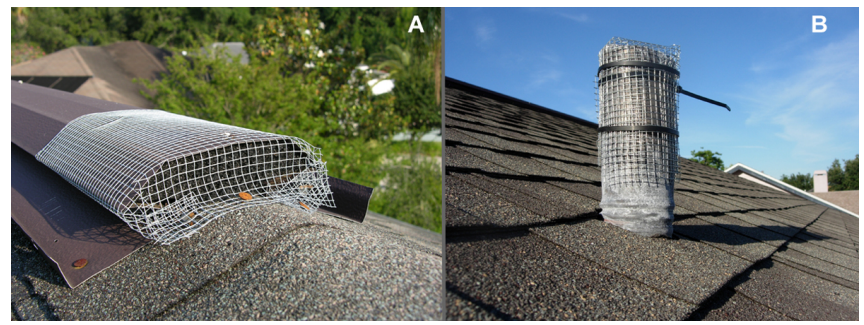

Figure 5. Roof vents (A) and plumbing vent stacks (B) often have large openings that can allow climbing snakes (such as rat snakes) to enter the home or garage. These large openings can be easily covered with hardware cloth, as shown here. Credits: Steve A. Johnson, University of Florida, 2007 
Pet doors can also serve as easy access points for snakes. The only effective way to exclude snakes from entering garages or homes via these access points is to seal or remove the pet door. Outdoor and indoor/outdoor cats capture and kill millions of frogs, lizards, snakes, and birds in the U.S. each year, and are often responsible for bringing snakes into homes - usually through pet doors!

\section{"Rodent Proofing" Your Home and Other Structures}

Finally, you should attempt to "rodent proof" your home, so that rodents do not attract snakes into your home, garage, or shed. Ratsnakes, in particular, are often found in attics, garages, or sheds when rodents are present, but leave when rodents are exterminated. Outside the home, be sure to keep bird feeders some distance from the house and do not feed in late spring and summer, when birds have plenty of food sources, as you may be feeding rodents as well. Mulch bins, where people compost food scraps, may attract rodents, so be sure they are secure and that their contents are not accessible to mice and rats (Figure 6).

In the garage, be sure to keep doors and windows tightly closed, seal all holes, keep the garage neat and keep clutter (especially cardboard boxes in which rodents like to nest) off of the floor. If you see rodents or find droppings, you may need to use traps or hire an exterminator to remove them. Avoid using poisons because poisoned rats that leave your garage may be scavenged by wildlife or pets, poisoning them too. In your home you should take care to keep basements and attics clutter free, seal all holes, and monitor for rodent activity. In your garage and home keep human food, pet food, and seeds for birds in tightly closed containers and periodically inspect for signs of rodent activity (chewed boxes, droppings, etc.). A metal garbage can with a secure lid is a good, rodent-proof place to store bird feed and pet food in your garage.

\section{Additional Prevention Tips}

If you frequently encounter venomous snakes and find that the measures described above do not deter them, you may consider using fencing in some areas (i.e., along edges of wooded areas or margins

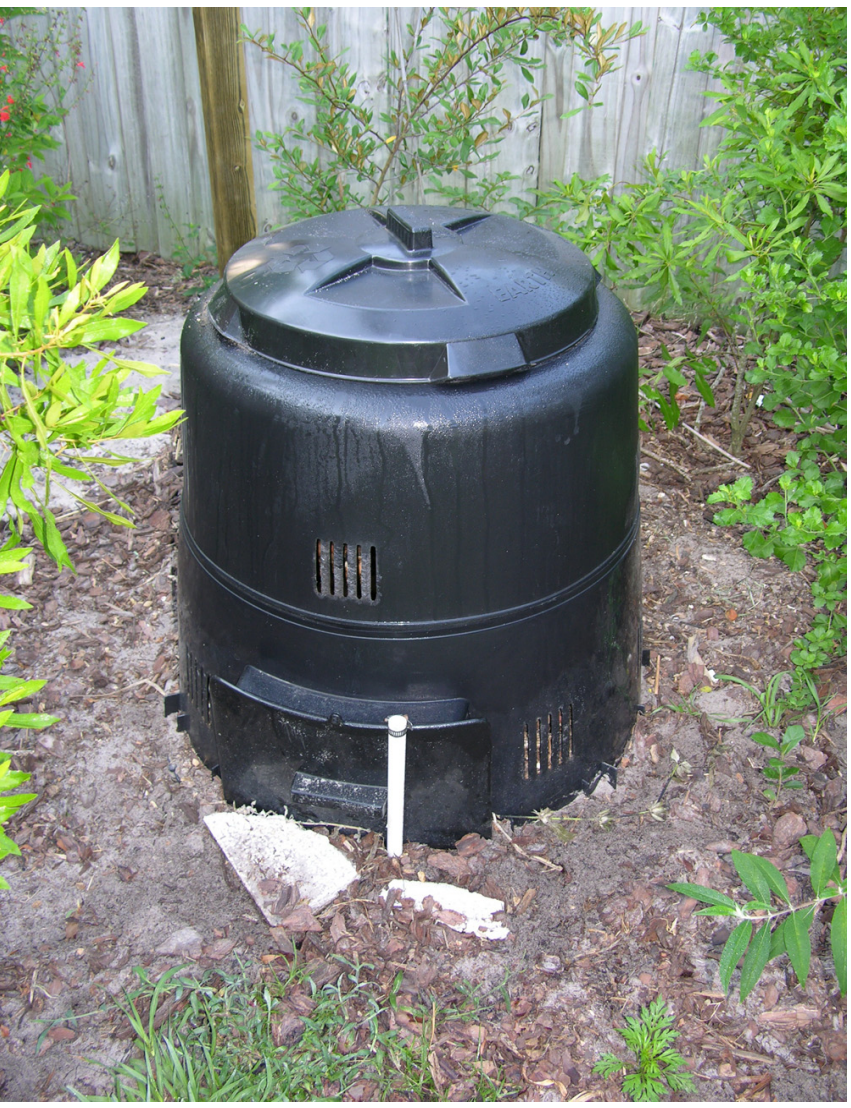

Figure 6. Mulch piles and compost bins can be inviting to rodents, which may attract snakes. Sturdy, sealed containers such as this can help to "rodent-proof" your yard. Note the PVC pipe used to hold the door securely in place. Credits: Steve A. Johnson, University of Florida, 2007

of lakes and wetlands) to prevent snakes from entering your yard. Fencing of aluminum flashing, hardware cloth (1/4"), or silt fencing 2-3 feet high buried 6 inches in the ground will deter most snakes from gaining access to certain areas of your yard (Figure 7).

If you use such a barrier along the edge of a wetland or forested area, be sure to turn out the ends of the barrier to direct potential snakes back into the natural habitats, rather than your yard. Using this method to exclude snakes from an entire yard can be costly and time consuming, and should be used as a last resort. If snake fencing is used to exclude snakes, be sure to trim vegetation well away from fence, as snakes may be able to use this to cross over. Also, be sure the posts or supports for the barrier material are on the side of the barrier toward your yard, as some snakes could potentially use the posts to climb over the barrier. Aluminum flashing and silt fencing (with 
posts already attached) are commonly available at hardware stores.

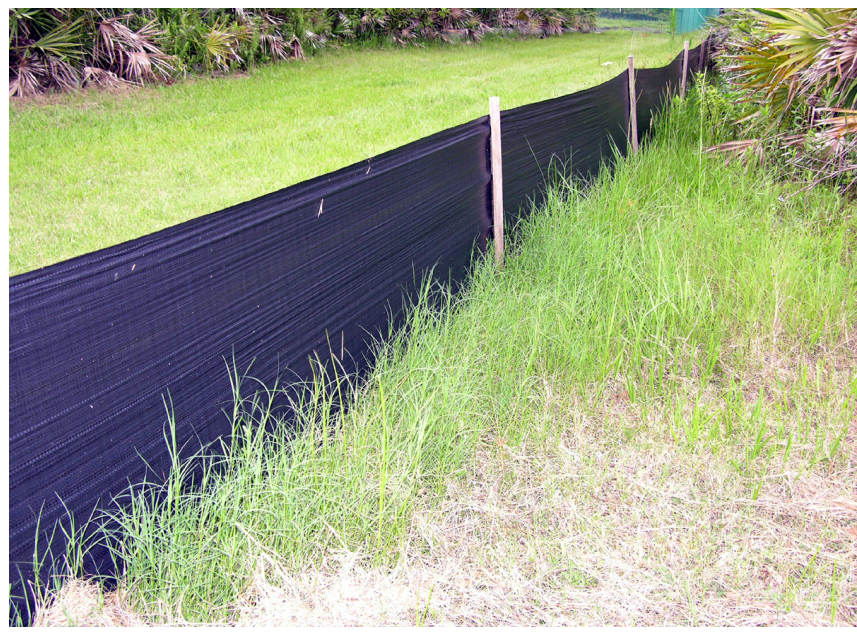

Figure 7. Snake fences, such as this one made of silt fencing, can prevent some snakes from entering your yard when used correctly, but can be costly and time consuming to install and do not prevent all species of snakes from entering. Such measures should only be used as a last resort. Credits: Steve Johnson, University of Florida

\section{SAFELY DEALING WITH SNAKE ENCOUNTERS}

If you have already read the previous document in this series (Dealing with Snakes in Florida's Residential Areas - Identifying Commonly Encountered Snakes: http://edis.ifas.ufl.edu/UW258), you should now be able to identify most of the snakes you may encounter in your yard and already know a bit about their behavior. However, it is critical that you also understand that snakes are not "aggressive" and do not hunt or chase people, but they can strike without coiling first. Belief in myths such as these can cause people to behave rashly during an encounter, creating an unsafe situation for themselves and for the snake. Above all else, if you encounter a snake, try your best to remain calm! Snakes would rather not encounter humans, and it is probably as scary for them as it is for you. Also keep in mind that the vast majority of encounters between people and snakes are with non-venomous, harmless snakes.

If you encounter a snake outdoors, keep children and pets away while you try to identify it as venomous or non-venomous - from a safe distance. Keep in mind that snakes will usually attempt to flee toward the nearest cover, so try not to stand between them and bushes or other cover. When they are startled, some snakes will flatten their heads and puff up to make themselves look more intimidating. A snakes may also become defensive or attempt to strike when cornered, so give it space! Remember releasing a foul smelling musk and striking are a snake's only defenses, since it has no claws. Be mindful of the fact that some non-venomous snakes (for example, Black Racers and rat snakes) will rattle their tails when they feel threatened, and if they are in dry leaves this behavior may give the impression that they are a rattlesnake. After you identify the snake, or at least determine that it is non-venomous, the best course of action is to simply "let it be." If you have taken the precautions described above, it will not be able to enter your house, will not have a ready supply of rodent prey nearby, and will likely soon be on its way. If you feel that you must remove the snake from your yard, spray it gently with a water hose to send it on its way while keeping your distance. If you find a snake in your pool, you can use a long handled leaf skimmer to gently remove the snake, as it may not be able to get out on its own if it is small or exhausted from swimming. If you determine that the snake is venomous or you are not sure of its identity, take a digital photograph and contact a professional! Do not attempt to handle the snake yourself! However, keep in mind that if you have taken the precautions described above, the snake is probably just passing through.

If you encounter a snake indoors, try to identify it as venomous or non-venomous from a safe distance while keeping children and pets away. Most snakes found inside Florida residences are non-venomous, and can be easily and safely removed using a large wastebasket or outdoor trashcan with a lid and a broom. Tip the trashcan onto its side, and use the broom to gently "chase" the snake into the trashcan. Then, tip the trashcan upright and, taking care to keep your hands away from the open top, replace the lid. You can then easily transport and release the snake in a nearby natural area. A full description of this technique, with accompanying photographs, is available online as part of the Florida Museum of History Online Guide to the Snakes of Florida (from link in additional resources, follow link to "getting along with snakes"). If you find a snake 
indoors in close quarters in an attic or basement and are not able to use this technique, there are a variety of humane glueboard snake traps, such as the Cahaba Snake Trap (http://www.cahabasnaketrapsales.com) that you can set along walls to capture snakes. When these traps are in use, they MUST be checked daily so that snakes do not die from lack of moisture and begin to smell. Captured nonvenomous snakes can easily be set free at a nearby natural area by pouring vegetable oil onto the snake to release it from the glue. If you have a venomous snake in your home, or if you capture a venomous snake in a glue trap, leave it alone and call a professional. To find a licensed wildlife removal specialist in your area, visit the nuisance wildlife permit web site maintained by the Florida Fish and Wildlife Conservation Commission (http://myfwc.com/license_permit/NuisWild.aspx). If you find a snake in the garage and are unable to capture it with a trashcan or glue board, simply close the door to your house and crack open the external doors to allow the snake to escape.

The identification tips provided in the second document in this series (http://edis.ifas.ufl.edu/UW258), along with the preventative measures and removal techniques described here will enable you to safely deal with snakes in and around your home. As you learn more about Florida's native snakes, we hope that you will also learn to respect them and appreciate their role in Florida's environment. However, it is also essential that you know what to do and what to expect in the event that you, someone you are with, a child or a pet is bitten by a snake - especially a venomous snake. The fourth and final document in this series, Dealing With Snakes in Florida's Residential Areas Emergency Planning (http://edis.ifas.ufl.edu/UW261) will provide you with the information you need to develop a plan for dealing with snakebite.

\section{ADDITIONAL RESOURCES}

This document is the third in a series of four documents by Dr. Steve Johnson and Monica McGarrity that provide information to Florida's residents on how to identify snakes that are commonly encountered in residential settings, how to prevent encounters from occurring in the first place, and how to respond in the unlikely event that someone is bitten by a snake. Anyone living in Florida, especially people new to the state, will find these documents useful. These documents are available online through UF/IFAS Extension Electronic Data Information Source.

1. Dealing With Snakes in Florida's Residential Areas - Introduction (http://edis.ifas.ufl.edu/UW257)

2. Dealing With Snakes in Florida's Residential Areas - Identifying Commonly Encountered Snakes (http://edis.ifas.ufl.edu/UW258)

3. Dealing With Snakes in Florida's Residential Areas - Preventing Encounters (http://edis.ifas.ufl.edu/UW260)

4. Dealing With Snakes in Florida's Residential Areas - Emergency Planning (http://edis.ifas.ufl.edu/UW261)

\section{Hotline Numbers:}

Poison Control Hotline: 1-800-222-1222

American Society for the Prevention of Cruelty to Animals (ASPCA) Poisoning Hotline:

1-888-426-4435 (charges may apply)

\section{Good Books on Florida Snakes:}

Conant, R., and J. Collins. 1998. Peterson Field Guide to Reptiles and Amphibians of Eastern and Central North America, 3rd edition. Boston:

Houghton Mifflin Company.

Carmichael, P., and W. Williams. 2004. Florida's Fabulous Reptiles and Amphibians. Tampa: World Publications.

Tennant, A. 2003. Snakes of North America: Eastern and Central Regions. revised edition. Houston: Lone Star Books.

Snake Resources on the World Wide Web:

Johnson, S.A. 2005. Dealing with Venomous Snakes in Florida Schoolyards Series. WEC199-202. Gainesville: Institute of Food and Agricultural Services. http://edis.ifas.ufl.edu/ 
TOPIC_SERIES_Dealing_with_Venomous_

Snakes_in_Florida_School_Yards

Johnson, S.A., and M.E. McGarrity. "Black

Snakes": Identification and Ecology. WEC214.

Gainesville: Institute of Food and Agricultural

Services. 2006. http://edis.ifas.ufl.edu/UW251

Florida Museum of Natural History-Online guide to Florida snakes:

http://www.flmnh.ufl.edu/herpetology/FLGUIDE/

onlineguide.htm

\section{Florida Fish and Wildlife Conservation}

Commission snake

page:http://www.myfwc.com/critters/snakes.asp

\section{Partners in Amphibians and Reptile}

Conservation (PARC) site:

http://www.parcplace.org/index.html

\section{Snake Handling Equipment:}

Midwest Tongs - http://www.tongs.com (we

recommend their Gentle Giant tongs)

Tomahawk Live Trap -

http://www.tomahawklivetrap.com (we recommend

their 60" Super Tube tongs with rubber cushions) 